\title{
Tough talker quits Congress for bioindustry
}

Meredith Wadman, Washington

A congressman fêted for his dogged pursuit of corporate wrongdoers has made a career change that some observers are finding hard to swallow. James Greenwood (Republican, Pennsylvania), who led recent attacks on conflict-of-interest policies at the US National Institutes of Health (NIH), is to become president of the biotechnology industry's major trade group.

Greenwood accepted the \$800,000-peryear job with the Biotechnology Industry Organization (BIO) on 21 July. He will complete his current congressional term and begin with BIO in January 2005.

"This whole thing makes a mockery of the oversight responsibility of Congress," says Vera Hassner Sharav of the Alliance for Human Research Protection in New York. "It invites industry to buy their congressmen when they don't like where they're heading," she says. Members of Congress make $\$ 158,000$ - less than a quarter of Greenwood's new salary.

Others insist that Greenwood has not been bought. "It's hard to believe he's for sale," says Arthur Caplan, director of the Center for Bioethics at the University of Pennsylvania, who knows Greenwood and has testified before him on stem-cell research. But he concedes that "there is something unnerving when the watchdog becomes the guard dog".

Caplan speculates that there may be a political motive underlying Greenwood's move. The increasingly right-wing House of Representatives may have become a tire-

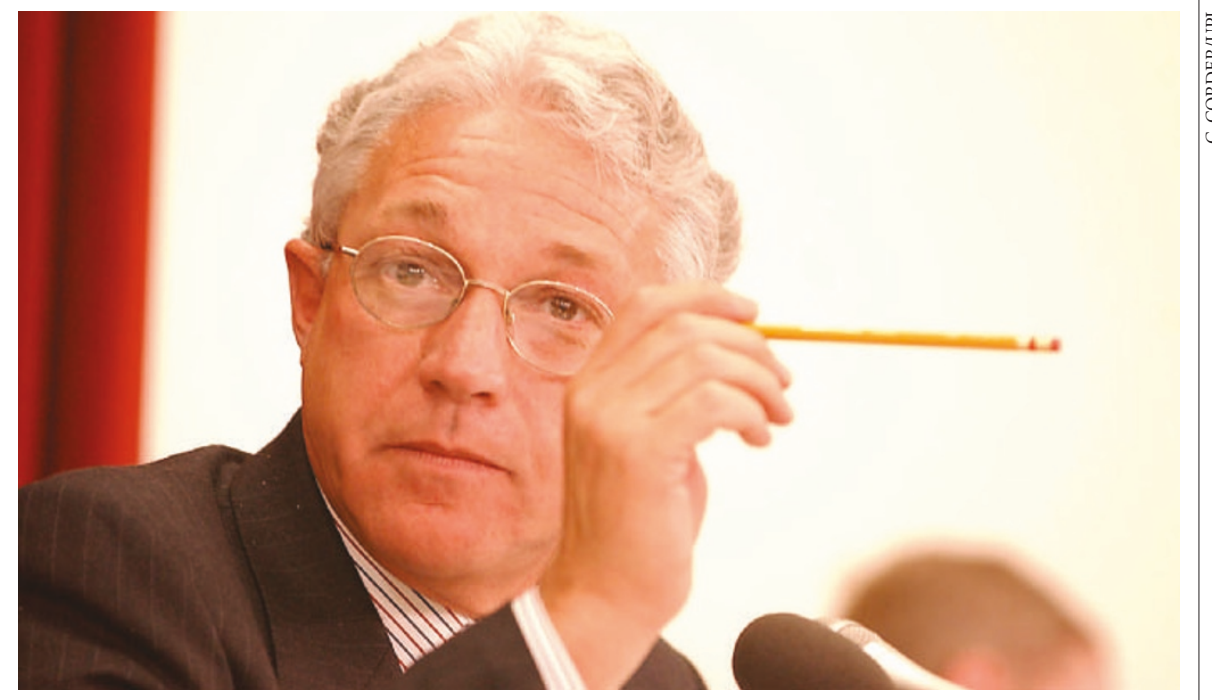

All change: James Greenwood is drawing a line under his congressional career.

some, hostile environment for a more liberal Republican such as Greenwood, he says. Greenwood has supported abortion rights, generous budget increases for the NIH and liberal policies on stem-cell research.

Since accepting the BIO job, Greenwood has excused himself from affairs that might conflict with his future work at BIO. Key among them is a hearing - abruptly cancelled on 20 July and now rescheduled for 9 September - at which big pharmaceutical companies are to be quizzed about their alleged failure to disclose negative results from trials of antidepressants in children (see Nature 429, 589; 2004). Among the expected witnesses are top officials from Pfizer, Wyeth,
Bristol-Myers Squibb and Eli Lilly — all of whom are members of BIO.

The hearing, which was to have been chaired by Greenwood, will now be chaired by another congressman. This has left some worried that without Greenwood's tough questioning the session won't be as thorough as first imagined. "This was to be a grilling," says Sharav. "What kind of hearing are we going to have now?"

Greenwood was not available for comment to Nature, but he released the following statement about his new job. "I passionately believe in the promise of biotechnology to find cures and treatments for the diseases that force parents to watch their children suffer and die."

\section{Biologists lobby China's government for funding reform}

David Cyranoski, Beijing

A group of prominent US-based Chinese scientists met with a high-ranking official from China's government last week to complain about the country's biased and inefficient system for funding life sciences. China is currently finalizing plans for several massive 15-year projects, but the researchers are concerned that not all of these are warranted and that they are absorbing too much of the science and technology budget.

Much of China's research is funded by the Ministry of Science and Technology, but for years the system has been criticized for its inefficiency and lack of transparency.

These criticisms came to a head following China's poor response to the outbreak of severe acute respiratory syndrome (SARS) in late 2002. As a result, a number of researchers both inside and outside the country called for the government to set up a Chinese equivalent of the US National Institutes of Health to guide funding in the life sciences (see Nature 428, 679; 2004).

But last week the science ministry rejected this proposal. Although researchers had worried that the plan would increase China's heavy bureaucracy, its rejection means that the funding system is still in desperate need of reform, they say. "It can't deal with conflicts of interest," says Haifan Lin, a stemcell biologist at Duke University in Durham, North Carolina. "It's not a valid system."

At last week's meeting, Lin and other members of the Ray Wu Society presented a letter to a senior adviser of Wen Jiabao, the prime minister, signed by 11 members of the society's board and outlining their concerns. The non-profit society, named after a plant biologist and composed of senior Chinese scientists based mainly in the United States, aims to develop the life sciences in China.
They say that their worries have been intensified by the science ministry's plans to assign funding to large projects covering 2006-20 by early next year. "The Chinese system encourages the control of large sums of money by a few people, without fair competition," says Tian Xu, a geneticist at Yale University and a member of the $\mathrm{Wu}$ society's board.

$\mathrm{Xu}$ and his society colleagues say that the country's other main funding organization, the National Science Foundation of China, does review projects fairly. But they point out that its annual budget of 2.2 billion renminbi (US\$266 million) is small compared with that of the ministry.

Over the next few weeks, Lin and his colleagues will try to ensure that their plea for a better funding mechanism reaches the prime minister. "We are approaching the government at the highest level," he says. 